\title{
THE INFLUENCE OF CUSTOMER SATISFACTION, BRAND TRUST AND BRAND IMAGE TOWARDS CUSTOMER LOYALTY
}

\author{
Nurul Sakinah Azizan ${ }^{1}$ \\ School of Business, Universiti Utara Malaysia (UUM), Malaysia. \\ (Email: kinazizan1@gmail.com) \\ Maha Mohammed Yusr ${ }^{2}$ \\ School of Business, Universiti Utara Malaysia (UUM), Malaysia. \\ (Email:mahayusr@gmail.com)
}

Received date: 08-08-2019

Revised date: 23-09-2019

Accepted date: 25-09-2019

Published date: 25-09-2019

To cite this document: Azizan, N. S., \& Yusr, M. M. (2019). The Influence of Customer Satisfaction, Brand Trust and Brand Image Towards Customer Loyalty. International Journal of Entrepreneurship and Management Practices, 2 (7), 93-108.

DOI: $10.35631 /$ ijemp. 270010

\begin{abstract}
Customer loyalty always becomes an important concern in the business organization. The main purpose of this study is to examine the influence of customer satisfaction, brand trust and brand image towards customer loyalty. This study focused on the branded computer product industry. The main problem in the industry is high competitiveness. It makes it hard for the manufacturer to obtain customer loyalty because of market competitiveness. Literature review regarding the computer industry in Malaysia and all items in independent and dependent variables has been discussed in order to provide a better understanding regarding past, present, and future needs in the study area. The in-depth review of literature has led to the establishment of a research framework focused on examining the influence of customer satisfaction, brand trust and brand image towards customer loyalty. In this regard, an online survey using Google forms was conducted among post-graduate students under the School of Business Management, Universiti Utara Malaysia. There are 269 students participated in the survey. The data collected through Google forms consist of six parts were analyzed using SPSS. The results showed that customer satisfaction, brand trust, and brand image have a positive and significant influence on customer loyalty. In conclusion, the discussion, and explanation on limitation, theoretical and practical implications, limitations, direction for future research. This study proved that long term success and sustainable reputation of branded computer product company depended on customer loyalty. The study recommends fulfilling customer expectation is the main priority to retain and enhance customer loyalty.
\end{abstract}

Keywords: Customer Loyalty, Customer Satisfaction, Brand Trust, Brand Image 


\section{Introduction}

Recently, competitive tendencies in the marketplace increased due to the globalization and deregulations which it attracts the attention among the business founder to cross borders and compete internationally (Namada, 2018). Customer expectations changed due to the advancement of technological, sophisticated which resulting to high competitiveness and give impact towards customer loyalty in the business sector specially to gain the customer among the students. In this study, the research focused on the customer loyalty towards the computer products. As we all know, computer is very important tool for students in terms of finishing their assignment, searching for information and downloading lectures notes. Hence, the practitioners in this respective sector have to investigate the most influence factor affect customer loyalty in the competitive marketplace in order to gain the trust among the customer especially students to purchase their products (Khuong et al., 2016). This business sector is important in order to enhance the economy stability and it played role in the global economy. It can be specifically stated that it contributed a total of $66.3 \%$ of the world gross product.

There are numerous empirical studies and literatures have stated that in order to attract customer loyalty to ensure it able to compete well with others. In addition, customer loyalty could be seen clearly when we focus on their satisfaction, brand trust and brand image. Hence, this paper focused on customer loyalty especially in computer product which highlighted on the students' scope. Customer loyalty is pillar of success in business practices. It is considered as big success when marketers held a strong brand name by gaining competitive advantages of customer loyalty (Al Otaibi et al., 2014). The competitive advantages could be seen through different aspects like how a firm reacted to competitors strong marketing pressure, how a firm maintain successful marketing plan and also how a firm try to deliver high quality product or services to create high barriers for new business to enter their market. These are things that help enhancing of customer satisfaction. In a nutshell, customer loyalty has been proven to give impact in influencing consumers to choose certain products that have good benefit and brand attributes.

It is crucial for the practitioner to enhance customer loyalty to ensure their marketing strategies well-suit with the current demands. Recently, the issues of customer satisfaction, brand image and trust become the main concerns among the researchers as well as marketers in order to improve their marketing strategies in order to gain customer loyalty. Consumer engagement requires from companies to think differently - from channel presence to articulating their value proposition and brand personality - while at the same time delivering personalized and consistent experiences across all channels. Brand must recognize the power of data in generating insights that can help them to deliver a rich, unique and personalized multichannel customer experience. Even as companies recognize the power of data and analytics, they may only be proficient in using analytics to generate insights on the past - but not for the future.

Computer industry is chosen due to the highly competitive among the various brands present in the market. Every brand purposed their pros and cons. Hence, as user, it is important to evaluate their pros and cons for further purchase intention. Computer is the essential technology that made student life effective. Computer has come with benefit of accuracy and time efficient compared to when you do it manually. As a user, the luxury of choice for further purchase intention mostly depends on price and function (Close et al., 2010). Thus, as the founder for the computer brand, it is crucial to ensure their products fulfill customer needs in order to gain customer loyalty. In this study, the focus is highlighted among the students where computer is important in student life for the sake of assignment, searching for information and 
reading materials as well as downloading lectures note. Hence, the computer manufacturers need to invest time and focus on customer satisfaction, brand trust and brand image to gain customer loyalty especially among the students.

Customer satisfaction is what a firm used to gain customer loyalty. In this study, customer satisfaction could be seen clearly when the customer@ student spread the positive feedback regarding the product they purchased. More than $50 \%$ of consumers say their loyalty depends on the brand or product/service (In Moment, 2018). It is one of the effective marketing strategies to ensure the customer satisfied with the product as well as promote the product to others. Past studies have proven that customer satisfaction does have influenced towards customer loyalty (Edward et al., 2010). The reasons why the customer satisfaction is important could be seen when they buy the product again and voluntarily promote that product to friends to show. Without them realizing, they have proven their satisfaction towards the product and showing customer loyalty. Besides, customer satisfaction known as powerful antecedent to customer loyalty as well as the medium to keep customers.

In today's competitive environment, building the loyalty of customer towards the brand has become crucial in marketing process. According to Motista (2018), consumers with an emotional connection to a brand have a $306 \%$ higher lifetime value, stay with a brand for an average of 5.1 years vs. 3.4 years, and will recommend brands at a much higher rate $(71 \%$ vs. $45 \%$ ). The brand trust will expose customers' spontaneous behavior when mutual trust among company and customer developed. Hence, company could increase customer commitment as well as get better word of mouth (Benedicktus et al., 2010). Besides, the reason why brand trust is important to ensure customer loyalty is due to good impression expressed by the respective product which makes the customer believe the respective brand can be trusted and will give better satisfaction to the consumer. On the other aside, Brand image is use as a tool to create certain perspective in customer's mind regarding what the brand represents. It is what distinguished one brand to their competitors. It has definite control on customer loyalty. A company or product that has a good image in the market is more likely to get a superior place in the market to ensure that they able to compete well with others. In addition, brand image also acts as the vivid characteristics that elaborate what a brand offers and what needs it satisfied according to the consumers. In any situation, consumer is the main and first priority which highly influences the value of the respective market.

Therefore, this study, the product focused was computer product and the target person are students who really need computer in their student life. Moreover, customer loyalty issues have been become attention among the researchers in the recent years in any business as well as computer products industry in line with the competition and growing demands among the users. In line with that, this study will target on understanding on how customer satisfaction, brand trust and brand image influence towards customer loyalty.

\section{Literature Review}

\section{Computer Industry in Malaysia}

In this study, computer industry is chosen by the researcher to examine the impact regarding customer satisfaction, brand image and trust towards customer loyalty on the computer product. The focus of this research highlighted on UUM Post-Graduate student. It is due to the generational cohorts in this recent era and globalization has different values, preferences and learning behavior. It is a main objective for marketers to evaluate such differences and produce products as well as services correctly. Computer is a product that has been used globally by 
individuals, universities and businesses. Elements that influences the usage of computer product in the current market that effected customer loyalty are usability, product customization, effective cost, customer service and service quality.

Gen Y will become the biggest consumer segment of technological product in over next five to ten years. As this being said, branded computer manufacturer needs to strengthen their strategies to gain a positive and lasting relationship with Gen Y by maximize their satisfaction, trust and loyalty. Considering that this segment is compromise by hard to pleased consumer that least loyal and strongly emotional, to capture their heart as a customer will be challenging work. Computer brand need to develop their own website parallel to the advancement of technology to attract customers and encourage their purchasing attention. Hence, the target customer could browse into the internet to gain the related information and decide the product fulfill their criteria or vice versa. According to Chan (2012), the innovation of technology has made computer industry changing fast compared to other industry and in fact, directly impact the production of industry. The combination of engineers, engineering technicians and also technical workers that heavily involved in research and development $(R \& D)$ is required by the manufacturer to catch up with highly changing of technological advancement and innovation. In other parts of the firm, the marketer has big responsibility in make sure product or services manufactured or offered by their firm is selling well. Hence, it is important for the respective company for example as focused in this study which is branded computer product company to enhance the factor which influence brand loyalty such as customer satisfaction, brand trust as well as brand image (Keller, 2012). Thus, the respective company able to compete well with the other companies in the similar areas as they able to counter the factors which influence brand loyalty.

\section{Customer Loyalty}

The word loyalty is connected to a feeling of strong attachment and affection. But from a business perspective, customer loyalty is meaning to gain customer trust towards the product as well as the services provided. All business used customer loyalty to measure their performance indicator in the respective business. It is used to retain the customers as well as measure their prosperity to repurchase the product. Aspect of customer loyalty required further attention among the marketer to improve customers' retention which could highly affect the profit margin. A loyal customer could be assigned when they feel that a brand develops and deliver the right product with exceeded quality. They will repeatedly making repurchase of that specific brand either they realize it or not. Nowadays, due to the competitive nature of doing business, gaining brand loyalty has become a very challenging task. It is important for the founder to create a systematic marketing strategy to gain customer loyalty (Ong et al., 2016). It could be seen clearly when the companies are trying their best to maintain and enhance their customer loyalty by gaining their satisfaction, customer loyalty going to be a reward for the firm (Aziz, 2017).

In addition, customer loyalty could be understanding as a response come from behavior of customer and as well as from psychological process. It is the combination of behavior and attitudes. The company could gain customer loyalty when they are repeating their purchase in future which can be seen within their decision to spread the positive words on the particular product towards others. It is also indicating emotional attachment and commitment towards the brand from consumer. True customer loyalty happens when they willing to associate themselves with a specific brand through repurchase behavior. 
Customer loyalty has been a hot issue in marketing and researchers' world recently (Huang and Cai, 2015). Hameed (2013) and Parker (2012) has stated that brand and customer loyalty can be a topic to study in various perspective. A strong customer loyalty can make a consumer develop constant commitment to repurchase even when they are facing situational impacts or strong marketing persuasion from other brands that try to create switching behavior. To create customer loyalty towards the product or services, brand loyalty work as a superficial element (Singh, 2016). The legit competitive industry has made organization need change. Now, not only they have to focus on selling their product or services, but they also need to take care of aftersales services to make sure customer will satisfy and come again to purchase (Doostar, Asil, \& Behrang, 2013). Wel, Alam, \& Nor (2013) has said that brand loyalty is a merely result of behavior and attitude. Repurchase cannot be the only evidence needed to prove customer loyalty. Researchers has mentioned that cost of doing business can be reduced by gaining customer loyalty. It then leads to maximization of company's profitability. Consumer will run free advertisement by spreading good words to other potential buyers. Loyal customers have become marketing agent for the brand without their realization. They will spread a good word to their family and friends (Li \& Chaipoopirutana, 2016), Ehsani (2015) this has resulted consumer as a valuable asset to organization.

\section{Customer Satisfactions}

Psychologist has stated that customer satisfaction derives consumer to pleasure as they get what they want and expect from purchasing product or services. It is an essential marketing tool. Consumer satisfaction has helping a firm resulted in winning and gaining competitive advantages that create long term relationship that help organization for a long-term success. Referring to Khristianto, Kertahadi and Suyadi (2012), comparison between the initial consumption expectation of consumer and the real experience after purchasing, lead to positive customer satisfaction. Marketing concept implementation need both loyalty and satisfaction for them to succeed. Satisfied feeling from customers are positively related to intention to repurchase. It is important to identify the variables which influence customer satisfaction and it will act as an indicator of high business performance and also serves as guideline for future improvement.

Customer satisfaction will come from exceeded buyer's expectations. If organization delivers lower performance then their expectation, dissatisfaction from consumer will arise. Kotler and Armstrong (2010), has stated that high performance will delight the consumer. Quality and satisfaction depend solely on product or services delivering by the firm (Perreault \& McCarthy, 2010). Alabar (2011) has concluded that a satisfied consumer not only birth into a loyal customer, but also become an agent of spreading favorable word about the brand, and resulted in sales enhancement (Alabar, 2011).

\section{Brand Trust}

Trust has proven to lead consumer to customer loyalty. Respectful valued exchange and effective communication has help build brand trust among consumers. According to research done by Singh (2016), a crucial factor for customer loyalty is brand trust. Customers that have brand trust are willing to spend extra money on specific preferred brand because they believe certain brand can provide elements such as uniqueness, function and most importantly quality that cannot be offer by their competitors. It proved that trust is an important factor in develop healthy and long-term relationship between brand and their customers.

Li \& Chaipoopirutana (2016), also found a positive trait offered by brand trust. It is believing that brand trust heavily influenced customer's attitude. No customer is willing to spend their 
money on brand that cannot provide some quality that indicates the ability to serve the consumers. It has been found that trust is a definite influence on commitment towards the brand. Li \& Chaipoopirutana (2016) also said that trust impact both purchase and loyalty. The qualifications set by the consumer themselves is what help build brand trust. There are two approaches of this concept. The first one is consumer's knowledge of the product and their emotions (Ramiz, Qasim, Rizwan, As-lam, \& Khurshid, 2014). Behavioural impact is the second approach. It is developed by confidence on the brand. It means that they believe in the brand and honesty of the firm in which the firm will deliver expected product or services they needed. Compassion, competency, and honesty will create brand trust which become major element and become bridge between brand and customers. In many past research and journal, trust function as element of loyalty and when it created, consumers will delight.

\section{Brand Image}

Brand allocated as the symbol, sign and name of the product. Brand image act as a symbol that represent product or services in consumer's conscious or unconscious mind. Product can be derived by three different images which are functional, social and perceived. Brand image in customer's mind can be a result from product appearance, attributes, and how product market their functions in consumers' lives. Not only has it represented functional aspect, but also as a representative of consumer's emotion (TsaiYuan \& Chang, 2013). On top of that, overall thought in consumer perspective is connected to ideas from consumer perspective to a particular product, brand, company, and person. Brand image is all impression that came from customer's perspective that they get from various output. By developing positive perspective towards the brand, brand image is formed in their mind.

In order for the brand to have a good brand image, it is crucial step for the firm to help build individual representation that can fulfil consumers' needs in psychological aspect and connected it with value like prestige and high place in social class. Using symbolism is a one way to approach brand image and it can impact an effort on gaining and retaining customer loyalty. In fast changing business, firm need to create among consumers the willingness to adapt change and lifestyle oriented, and then implied that they can use the brand to represent themselves. By doing this, they will attach themselves with the brand and at the same time it will create loyalty. In nowadays world that focusing on material aspect, brands have become influencing aspect in order for consumers to considering choosing a product or services. There are many ways done by organization in order to enhance and up level the image of their brand, as they believe it can lead to consumer loyalty. For example, brand name is one of basic aspect that a firm need to focus on developing brand image. It all started with a name. Having a suitable product or services name is a gift that a firm need to gain. From a name, a firm can then develop brand identity. Brand name lead to consumer loyalty, according to branding theory. It stated that brand image that firm try to portray should be similar to consumers' image, so that it can meet consumer's psychological and social needs. Wealth, class, success and style if a few traits that consumers try to find in a certain brand (Shehzad \& Zehra, 2013).

\section{Hypotheses Development}

This study uses social exchange theory as the underpinning theory to explain the relationships among the variable included in the framework. Social exchange theory is a broad conceptual paradigm that spans a number of social scientific disciplines, such as management, social psychology, and anthropology. Despite its name, it is not a single theory but is better understood as a family of conceptual models (Cropanzano \& Mitchell, 2005). In this regard, all social exchange theories share a number of common features. All social exchange theories treat social life as involving a series of sequential transactions between two or more parties 
(Mitchell, Cropanzano, \& Quisenberry, 2012). Building on these straightforward ideas, social exchange theory is one of the most enduring and widely used conceptual frameworks (Cropanzano \& Mitchell, 2005). According to Schyns \& Schilling (2013), presumably, a positive social exchange relationship would be less likely to develop low commitment, for example. It is also possible that the resulting exchange could be economic, as individuals are less apt to find close and open-ended associations with those who hurt them. In either case, the quality of the relationship would be low, as mutually beneficial interchanges are less likely to be engendered when people are transacting in harm.

This brief review suggests that social exchange theory is an extremely broad conceptual framework that has proven itself capable of describing almost any reasonable pattern of findings, at least in a post hoc manner. In this study, the product which is computer attract the social exchange among the students due to their needs in order to ensure their student's life did not distract in order to doing their assignment, finding the information as well as downloading lecture materials. Social exchange is an important aspect that focus on consumer as main element of marketing world. Each of consumer come with need and want which is different, unique and special. Social exchange is connected to human interaction between a brand and consumer that result in purchase decision. It is complex multidimensional variable (Alexander, Khonglah and Subramani, 2015).

One of the aspects that influence purchase is interactivity. It said to play an important drive to make customer more confident before deciding on the purchases. When connectivity and interactivity combined, business model that driven by content that goes hand by hand with technology, producing high effect that helps marketers in reaching to current and potential consumer (Hanna et. al, 2011). This is the process of building brand trust and brand image for the brand itself. All of this not only lead to purchasing, but also customer loyalty. Due to the interactivity, it could be good marketing strategy to attract customers' buying behavior (Amora et al., 2015). In order to ensure the marketing concept, fit in with the current market, the marketers need to find what kind of benefits that consumer intend to get from them, followed by detailed marketing mix that help them achieve customer satisfaction. It can be related to this study where the consumer focused is students. Hence, the marketing strategies need to fit with students' life. For example, the marketing strategy could be special price for students, special gift for the specific purchase and also vouchers based on the purchasing values.

Nowadays, computer is the important asset for students to ensure them able to suit themselves in campus life which are busy with assignments and programs. Due to the effective marketing strategies, the students will be attracted to buy the products and also give positive feedback based on the products they bought. Hence, the marketer needs to discover how customer behavior works as it will become powerful tools to understand customer. On top of that, customers are who translate into sales and profits of the organization by doing purchasing decision (Pappas, 2016). Social Exchange Theory (SET) could be directly or indirectly involved with customer satisfaction, brand trust and brand image. When the customers have satisfied with the interaction and product or service offered by a brand, they tend to repeat buying the product as well as spread the positive words to others. Customer is the main priority to ensure the marketer able to withstand longer. Accordingly, the following hypotheses have been developed.

\section{Relationship Between Customer Satisfaction and Customer Loyalty}

In marketing, customer satisfaction acts as a key of operational element in order to sustain customer behaviour (Bowen \& Chen, 2015). Besides that, customer loyalty towards the brand 
and product able to enhance business value and cost-effectiveness to business. It could be seen that these two elements have impact on higher business decision. According to past literature, it positively showed the relationship of customer satisfaction towards the customer loyalty.

Referring to the past studies conducted by Li \& Chaipoopirutana, customer satisfaction highly correlated with customer loyalty. Both aspects are compliment to each other ( $\mathrm{Li} \&$ Chaipoopirutana, 2014). There are numerous researches proved that there is a direct relationship between customer satisfaction and customer loyalty. It can be concluded that satisfaction is crucial to gain customer loyalty or otherwise it will become the main reasons why the consumer tend to switch their intention towards the other brand.

Therefore, the researchers suggest below hypothesis:

H1: There is a positive relationship between customer satisfaction and customer loyalty

\section{Relationship Between Brand Trust and Customer Loyalty}

Past studied has already prove that brand trust was indeed, a key factor that engaged towards brand loyalty. Razim et al, (2014), stated that trust is the key to help customer build commitment to the brand. Trust work as a basic element to build strong marketing connection and it will result into confidence towards the brand. It is conceptually connected with customer loyalty (Farhanullah \& Adeeba, 2013). Thus, the second hypothesis was suggested as follows: $\mathrm{H} 2$ : There is a positive relationship between brand trust and customer loyalty

\section{Relationship Between Brand Image and Customer Loyalty}

Strong customer loyalty can be understood as direct impact from success process of branding the image of the brand. Sasmita and Suki (2015) said that brand image it is the powerful variable which bring competitive advantage and organizational success to ensure their product able to compete in the market. Customer behaviour in terms of service supplier is connected as customer willingness to stay loyal to a certain brand and their respective product (Leckie et al., 2016). Thus, clearly brand image has a direct relationship with customer brand loyalty (Nyadzayo \& Khajehzadeh, 2016).

With the advancement in technology, business and individuals had kept their hand up to date. The changes of the high-growth technologies had opened up opportunities for a lot of companies. The transition of traditional approach to influence customer loyalty towards the products to more competitive ways looks appealing to many of the customers of the respective products nowadays. As important as it be in gaining customer loyalty, brand image is a one element that has deep complexity. It is because human has a complex thinking that not that easy to understand. Even with continuous survey and study, human change all the time. So, it is not easy to build a brand that will make consumer appreciate as a part of image that will present them as a human being. Individual wants another person to see and judge them by the product or brand that they endorse. Past research believes that brand image that reflects selfimage of the consumer will result in strong customer loyalty.

Brand image resulted in customer or brand loyalty in two ways; first, customer use the brand image as their own and the second way is when customer divide themselves in different social class by using the product they used as items of evaluation of their values. Luxury brand image resulted in purchasing decision and later repurchase intention. Therefore, the third hypothesis was created as mentioned below:

H3: There is a positive relationship between brand image and customer loyalty Figure 1 below indicates the flow of the relationships among the variables. 


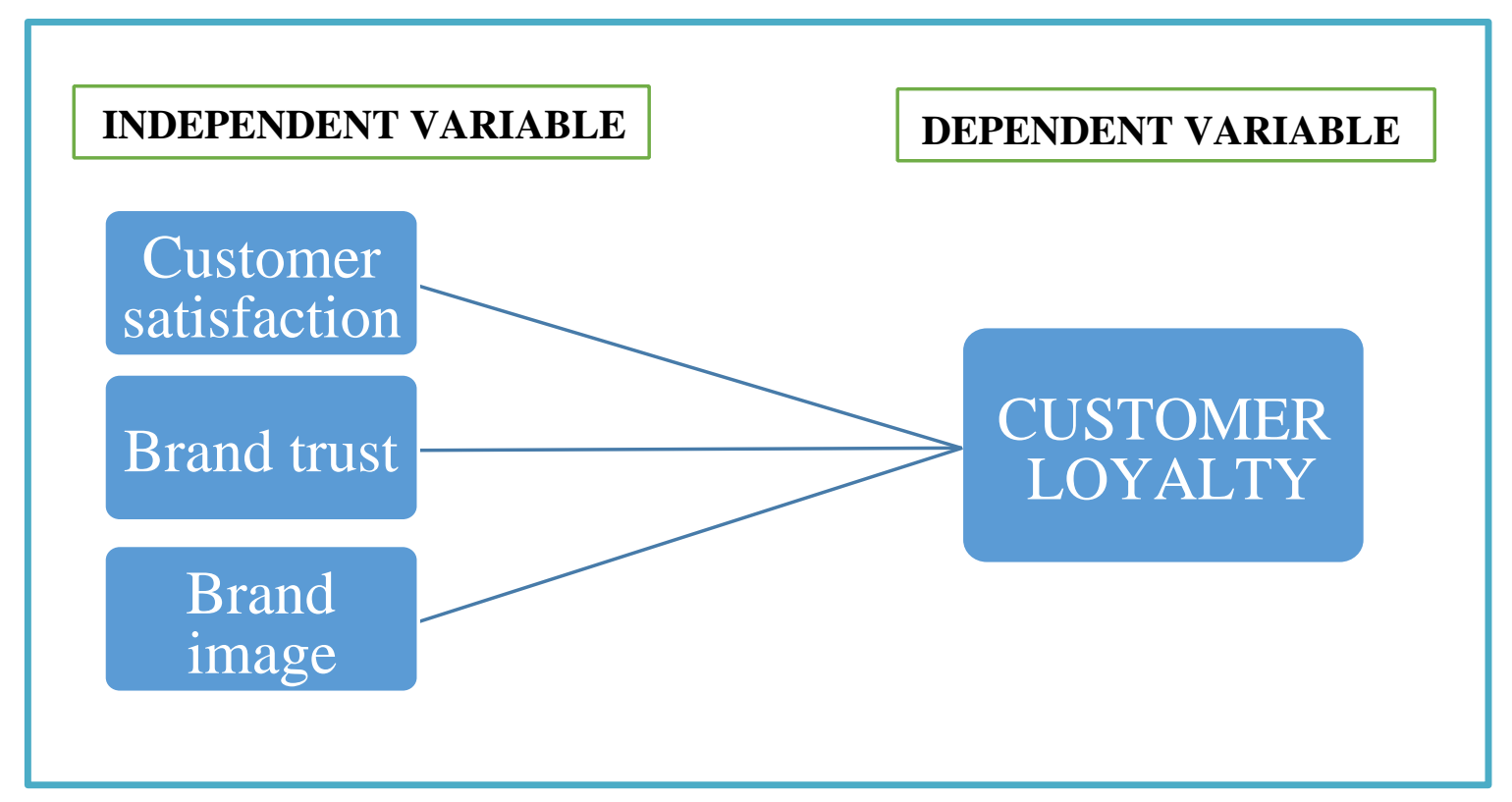

Figure 1: Research Framework

\section{Methodology}

This study is a quantitative study, where the descriptive and cross-sectional method were adopted to collect the data and achieve the study's objectives. This research objective was to examine how customer satisfaction, brand trust and brand image impact customer loyalty using branded computer product as indicator. The research design employed by two types of variables, dependent variables and independent variables. A detailed questionnaire was distributed to the respondents to collect data needed for this research. The population of this study was 908 Post-Graduate students under School of Business Management, Universiti Utara Malaysia (SBM, UUM, 2018). The targeted sample (i.e., UUM students) was determined due to the accessibility of the researchers to the respondents and the limit time frame to conduct the study. The researchers used random sampling method as the sampling method for this study. In statistics, probability sampling refers to the sampling method in which all the members of the population have a pre-specified and an equal chance to be a part of the sample (Key Differences, 2016). This technique is based on the randomization principle, wherein the procedure is so designed, which guarantees that each and every individual of the population has an equal selection opportunity. This helps to reduce the possibility of bias. Statistical inferences can be made by the researchers using this technique, i.e. the result obtained can be generalized from the surveyed sample to the target population.

There are several common types of probability sampling which includes the simple random sampling, stratified random sampling, cluster sampling, systematic random sampling, and double sampling (Cooper \& Schindler, 2011; Hage, 2013). This study incorporated the Stratified Random Sampling: Divide the population into "strata". There can be any number of these. Then choose a simple random sample from each stratum. Combine those into the overall sample. That is a stratified random sample. In this study, 611 post-graduate students are Master student and 297 is $\mathrm{PhD}$ students. It means $67 \%$ of questionnaires was distributed to Master students and $33 \%$ to $\mathrm{PhD}$ students. A common goal of survey research is to collect data representative of a population" (Williams, Bartlett, Kotrlik, \& Higgins, 2001). However, due 
to cost and feasibility constraints, the researcher cannot afford to investigate the whole population. They added that adequate sample and high-quality data collection efforts will lead to resource savings as well as reliable, valid and broader result. In this study, researcher depending on Krecjie and Morgan's (1970) to determine the sample size. Referring to Table 3.1, since the population is at (N) 908, sample size needed is at least (S) 269 respondents. Thus, researcher had distributed 300 copies of survey forms to the customer.

The researcher used a set of questionnaires to collect the data. A set of questionnaires were adapted from its previous research (such as: Oliver (1997), Sirdeshmukh, Singh and Sabol (2002), Khadijah (2010), Lassar, Mittal and Sharma (1995), Chaudhuri and Holbrook (2001), and Khadijah (2010), Law and Lamb Jr (2000) and Hashed (2016), Oliver (1997), Mols (1998), Pritchard, Havitz and Howard (1999), Kim, Han and Park (2001), Sirdeshmukh, Singh and Sabol (2002), Chaudhuri and Holbrook (2001), Yang and Peterson (2004), and Khadijah (2010). All variables being measured by using Likert Scale measurement. The scale ranging from 1-strongly disagree, 2-disagree, 3-natural, 4-agree and 5- strongly agree.

\section{Data analysis}

The data revised by the researchers for completeness and accuracy. The questionnaire coded and analyzed using IBM SPSS version 25.0. Researchers used regression to determine the relationship between variables. Table 1 below describes the result of testing hypotheses by using regression analysis.

Table 1: Multiple Regression Result

\begin{tabular}{lllll}
\hline Hypotheses & Path coefficients & T-value & P-value & Decision \\
\hline $\mathrm{H} 1: \mathrm{CS} \rightarrow \mathrm{CL}$ & 0.262 & $4.771 * * *$ & 0.000 & Accepted \\
$\mathrm{H} 1: \mathrm{BT} \rightarrow \mathrm{CL}$ & 0.275 & $5.580^{* * *}$ & 0.000 & Accepted \\
$\mathrm{H} 1: \mathrm{BI} \rightarrow \mathrm{CL}$ & 0.417 & $7.723 * * *$ & 0.000 & Accepted \\
\hline
\end{tabular}

Note: $* * * \mathrm{p}<0.01$

\section{Discussion}

In the fierce competition in the products industry especially computer accessories, it has been given the status of commodity, where the brand founder needs to find a way to make their product special and differ from others. Thus, customer satisfaction seems an important key to achieve success. Competition seems increasing fierce. With the huge number of competitions in this sector, customer loyalty has become one of the crucial aspects of sustainable competitive advantage (Ganiyu et al., 2012). Recently, there are a great competition could be noticed in business organization as well as marketplace. Hence, it is essential for the marketers to create marketing channel effectively to ensure they able to compete well in the growing market. Hence, customer loyalty recognized as one of the effective ways to maintain and retain customer. In addition, today's consumers become more demanding and had more bargaining power. Hence, as the founder of the product, it is necessary to increase customer satisfaction which gives positive influence towards the customer loyalty. Thus, the marketers and companies who able to satisfy and fulfil their customer needs, will remain as market shareholder and able to expand their market value in the superior stage. 
At a glance, brand trust is one of the crucial components that help strategize business marketing plan as well as customer satisfaction. In order to maximize brand trust among the customer, it is necessary for the founder to find an effective ideas and methods to ensure their product trustworthy. For example, in this business area, the customer will buy the computer or the parts of the computer after taking a closer look such as their specification, model, warranty and etc. the product and its features, functions, reliability are the most important aspects to enhance customers' trust. Therefore, disappointment after purchase can be avoided. Customer will purchase the product as they have a great trust on the respective product and brand. It could be said that brand trust is a barometer which used to predict the customer purchasing attention. As the product meets the specification and satisfaction of the customer, there will be repurchase. On top of that, they also help gaining new customer for a firm by spreading positive words of mouth (Hague \& Hague, 2016). Providing quality product is not only to satisfy the customer and gain trust from the customer, but also to have a safe position. In order to gain brand trust among the consumer, it is important for the marketer to provide the specific product or services with the specific perceptions in terms of usage, features as well as their quality. In addition, it will influence the emotion of the customers as well as their loyalty towards the respective product.

In marketing strategies, the marketers need to focus on the trust, commitment and attraction which are important element in order to create significant relationship to gain customer loyalty. But, a good relationship among partners like supply chain is also important. Good relationship among the business partner could avoid any conflict which could give negative effect towards the customer loyalty. In any business, the most important assets are customers or so-called long-term customers. The good relationship with the customer could be seen through the lifetime value when a firm give positive perception that directly reflecting their brand itself.

Shahin et al., (2015) has come out with definition that brand image is signal that a firm sending to their customer's mind through brand association. Based on what firm has created, it helps build customer's perspective towards brand. Auka et al., (2013) also said that brand image work as set of association build by a firm to make is valuable to the consumers. It is defined by a uniqueness offer by a firm regarding their product or service (Almaamari, 2017). On top of that, customer buying behaviour easily tampered with by the way a firm choose to portray their brand image. It should be tempting and fulfilling towards customer need and want. Saleem et al., (2014), believe that the higher mark a firm gets from their consumer regarding a firm brand image, the higher they believe that a firm's product or services possessed superior value and quality. Furthermore, McIlraith (2014) has conduct an experiment research that come out with a conclusion that consumers' perception about level of quality is related to a firm brand image. The concept of brand image can be regarded as a precursor to customer loyalty. It acts as a powerful agent or competitive advantage and organizational success. There is a direct and positive outcome on customer loyalty as well as purchasing attention. Referring to the finding obtained in the study, a relationship between brand image and customer loyalty t-value is 7.723 and $p$-value is 0.000 which indicates the relationship as significant. The brand image of the product gives significant effect towards the customer to choose the product for purchasing purpose. For example, it can be enhancing through the promotional activities to ensure the brand image well established. The founder of the product has to find the popular and influenced person to become ambassador to ensure the customer attracted to the respective brand. It is one of the effective ways to enhance customer loyalty towards the product via brand image. 


\section{Implications and Future Studies}

This study has a number of implications of factors influencing customer loyalty among the customer of branded computer products in business sector as well as for practitioners. As for the researchers in the respective field, this study will help them to understand more about relationship between the factors influencing customer loyalty in terms of customer satisfaction, brand trust and brand image towards branded computer product. Furthermore, they will be more aware that this situation is crucial in achieving good selling and also improve their marketing strategies. This research can be used as a fundamental of more deep study in the future. For marketers, better understanding on customer satisfaction, brand trust, and brand image will help them to make better decisions pertaining in gaining and retaining customer loyalty.

However, as all studies this study faced several limitations. Firstly, the researcher running of time to conduct the survey on the factors influencing customer loyalty towards the branded computer products due to short time provided to collect the data as well as analyze the data. In addition, the number of respondents for this research also limited which only comprising of 269 post-graduate students under School of Business Management Universiti Utara Malaysia. This situation caused the data insufficient for the analysis purpose which cause inaccuracy for the research finding. Moreover, there are several students do not give cooperation and commitment during the survey conducted. Besides that, another factors influencing customer loyalty towards the branded computer products not be discussed because of factors like lack of information and data.

This study can be foundation of future to study about comparison among customer of branded computer products and other business sector to evaluate the factors which influencing the customer loyalty. The area of survey can be expanded to the whole area in Malaysia to evaluate the most important factors which influence customer loyalty towards the branded computer products. Besides that, the number of samples can be increased which help to increase the accuracy of the finding on the factors which influenced customer loyalty towards the branded computer products. In addition, the researchers also suggested to conduct T-test in order to demonstrate min score towards the factors influencing customer loyalty in terms of customer satisfaction, brand trust and brand image. Other researcher can also examine other variables that they thought have impact towards customer loyalty of branded computer products like the influence of social media. Different method like qualitative research can also be applied like using interviews or observations. Other researcher should also try to use other population. It might lead to different findings.

In terms of enhancing customer loyalty, there are several ways can be implemented:

First; Sales performance will tell if the promotional activities are working in order to enhance customer loyalty. Unless the sale response to the promotional activities is immediate and overwhelming, it is almost impossible to use sales data to judge the effectiveness. Hence, it is recommended to keep a check on the sales performance and depending upon the result of the customer purchase decision it should be altered. Second; Regular surveys should be conducted regarding the effectiveness of the promotional activities as it is mandatory for the marketer to remain updated with the customer demand. Third; today innovation is the key to success. Sophisticated promotional mix can help in attracting customers with regular offers with match up the latest trends in order to capture the market. 


\section{References}

Agresti. (1997). Statistical Methods for the Social Sciences. Upper Saddle River: Prentice Hall. Alkhawaldeh. (2016). Brand equity and brand loyalty: New perspective. International Review of Management and Marketing, 6 (4):722-730.

Almaamari. (2017). The Relationship Between Total Quality Management Practices and Individual Readiness for Change at Petroleum Exploration and Production Authority in Yemen. 48-55.

Amaro. (2015). An investigate model of consumers' intention to purchase travel online. Tour Management, 46, 64-79.

Anantha. (2013). The effect of marketing mix and customer perception on brand image. Journal of Business and Management, Vol. 4, Issue 2, 01-11.

Anderson. (2010). The Web dead long live the Internet. Retrieved from https://www.wired.com/2010/08/ff-webrip/

Asmayadi. (2015). The Impact of Service Quality and Product Quality towards Customer Loyalty through Emotional and Functional Values in Traditional Markets in Pontianak, Indonesia. European Journal of Business and Management, 128-135.

Auka. (2013). Perceived service quality and customer loyalty in retail banking in Kenya. British Journal of Marketing Studies, 1 (3): 32-61.

Autry. (2018). 2018 Customer Engagement \& Loyalty Statistics. Retrieved from https://blog.accessdevelopment.com/2018-customer-loyalty-statistics

Aziz. (2017). Investigating critical success factors of brand loyalty: A Meta Data Analysis. International Review of Management and Marketing, 7(3): 233-237.

Bahari. (2016). Determinant of Customer Loyalty: Empirical Study of Semen Gresik Brand. International Business Management.

Benedicktus. (2010). Conveying trust worthiness to online consumers: reactions to consensus, physical store presence, brand familiarity and generalized suspicion. Journal of Retail. 86(4) 322-335.

Bhattacherjee. (2012). Understanding Information Systems Continuance an Expectation Confirmation Model. Volume 25, 351-370.

Boisvert. (2011). Towards a better understanding of factors affecting transfer of brand association. Journal of Consumer Marketing, 28 (1), 57-66.

Bernett. (2018). PC sales are continuing to slump, fewer are sold now than when the iPhone launched. Retrieved from https://www.businessinsider.my/pc-salesslump-to-decade-low-charts-2018-1/? r=US\&IR=T

Bowen. (2015). Transitioning loyalty programs: A commentary on the relationship between customer loyalty and customer satisfaction. International Journal of Contemporary Hospitality Management, 27 (3), 415-430.

Cengiz. (2010). Measuring customer satisfaction: must or not. Journal of Naval Science and Engineering.

Chan. (2012). Product placement and its effectiveness: A systematic review and propositions for future reserach. . The Marketing Review, 12 (1),39-60.

Deari. (2013). Consumers trust in the global brands: empirical analysis in the context of consumer perspective. European Scientific Journal, 9 (1), 61-74.

Doostar., Asil, \& Behrang (2013). Factors and Elements Influencing Brand Loyalty: A case study in customers of Khazrgaz in Mazandaran. International Journal of Agriculture and Crop Sciences, 6, 712.

Edward. (2010). The impact of switching costs upon the service quality-perceived value customer satisfaction-service loyalty chain: a study in the context of cellular services in India. Services Marketing Quarterly 31 (2), 151-173. 
Eggers. (2013). The impact of brand authenticity on brand trust and SME growth: A CEO perspective. Journal of World Business, 340-348.

Evans. (2008). Towards a Model of Understanding Social Search. 485-494.

Farhanullah. (2013). Factors Affecting Brand Loyalty in Pakistan Brand Loyalty of Apple IPhone in Pakistan KABIT, Karachi.

Ganiyu. (2012). Is customer satisfaction an indicator of customer loyalty. Australia Journal of Business and Management Research, 2 (70), 14-28.

Hague. (2016). Customer Satisfaction Survey: The customer experience through the customer's eyes. London: Cogent Publication.

Hameed. (2013). The effect of advertising spending on brand loyalty mediated by Store image, perveived quality and customer satisfaction: A case of hypermarket. Asian Journal of Business Management, 5(1), 181-192.

Hanna. (2011). We're all connected: The power of the social media ecosystem. Business horizon. 54 (3), 265-273.

Hartbeat, C. (2017, 7 4). Why customer feedback is important. Retrieved from http://blog.clienthaertbeat.com/why-customer-feedback-is-important

Huffcut. (2004). The impact of job complexity and study design on situational and behavior description interview validity. International journal of selection and assessment, Vol 12, Issue 3, pp 262-273

Inha. (2012). Brand Image and Brand Awareness. Case Study: Finnair in Indian Market.

Isoraite, M. (2016). Customer Loyalty Theoretical Aspects. Eco forum, 5 (2), 1-8.

Joshi. (2018). Is Consumer Loyalty Dead. Retrieved from https://www.ey.com/sg/en /issues/ey-spotlight-on-business-issue-1-2018-is-consumer-loyalty-dead

Kamisan, K. (2010). Relationship Between Customer Satisfaction, Brand Trust and Customer Brand Loyalty. Universiti Utara Malaysia.

Keller. (2012). Understanding the richness of brand relationships: Research dialogue on brands as international agents. Journal of Consumer Psychology, 22(2), 186-190.

Key Differences. (2016). Difference between Probability and Non-Probability Sampling Retrieved from https://keydifferences.com/difference-between-probability-andnon-probability-sampling.html

Khan. (2013). The Effect of Brand Characteristics on Brand Loyalty: A study of Cosmetics Products in Peshawar Pakistan. International Review of Basic and Applied Sciences, 1 (1), 1-11.

Khoung. (2016). The Factors Affecting Customer Satisfaction and Customer Loyalty : A Study of Local Taxi Companies in Ho Chi Minh City, Vietnam. International Journal of Innovation, Management and Technology, 7 (5), 228.

Khristianto. (2012). The influence of information, system and service on customer satisfaction and loyalty in online shopping. International Journal of Academic Research, 4(2), 2832.

Kim. (2012). The effects of perceived social media marketing activities on costumer equity and purchase intention: focus on luxury fashion brands. Yonsei University.

Kinney. (2010). Beyond buying: motivations behind consumers' online shopping cart use. Journal Business, 986-992.

Kotler. (2013). Marketing Management: An Asian Perspective. Singapore: Prentice Hall.

Krejcie. (1970). Determining sample size for research activities. In Educational and Psychological Measurement, 30, 607-610

Kruger. (2013). Investigating brand romance, brand attitude and brand loyalty in the cellphone industry. Act Commercial, 1-10.

Laudon. (2010). E-commerce: Business, Technology, Society. Upper Saddle River: Prentice Hall. 
Leckie. (2016). Antecedents of consumer brand engagement and brand loyalty. Journal of Marketing Management, 32 (5), 558-578.

Li. (2016). The Important Factors that Influence on Building Brand Loyalty Towards Chang'an Car Brand in Xi'an, Shaanxi, China.

Liu. (2016). Enhancing the flow experience of consumers in China thought interpersonal interaction in social commerce. Computers in Human Behavior, 58, (306-314)

Mahamad. (2010). Service quality, customer satisfaction and loyalty: A test of mediation. International Business Research, 3(4),72.

MCllraith. (2014). Creating Customer Loyalty Through Service Customization. American Scientific Research Journal for Engineering, Technology and Science, 11(1).

Mebhead, H. A. (2016). The direct and indirect influence of brand image, brand experience and brand personality on brand loyalty. Universiti Utara Malaysia.

Namada. (2018). Organizational learning and competitive advantage. In Handbook of Research on Knowledge Management of Contemporary Business Environments. IGI Global. (86104)

Nyadzayo. (2016). The antecedents of customer loyalty: A moderated mediation model of customer relationship management quality and brand image. Journal of Retailing and Consumer Service, 262-270.

Ong. (2016). The role of Emotional and Rational Trust in Explaining Attitudinal and Behavioral Loyalty: An Insight into SME Brands Gadjah Made. International Journal of Business, 18 (1), 1-19.

Pappas. (2016). Marketing strategies, perceived risks and consumer trust in online buying behavior. Journal of Retailing and Consumer Services, 29, 92-103.

Parker. (2012). Candidate brand equity valuation: A comparison of US presidential candidate during the 2008 primary election campaign. Journal of Political Marketing, 11(3) 208230.

Piaw, C. Y. (2012). Mastering Research Methods. Asia: McGraw-Hill Education.

Ramiz. (2014). The Comparative Analysis of the Factors Effecting Brand Loyalty towards Samsung Products. Journal of Sociological Research, 5, 327-349.

Ronaldo. (2015). Factors Influencing Brand Loyalty towards Sportswear in Bandung.

Journal of Business and Management, 8.

Rubio. (2014). Brand awareness-brand quality inference and consumer's risk perception in store brands of food products. Food Quality and Preference, 32, 289-298.

Russell. (2017). Social Exchange Theory: A Critical Review with Theoretical Remedies. Academy of Management Annals, Vol. 11, Issues 1, Pg 1-3.

Saeed. (2013). Effect of Brand Image on brand loyalty and role of customer satisfaction in it. World Applied Sciences Journal, 26 (10), 1364-1370.

Sagala. (2014). Influence of promotional mix and price on customer buying decision toward fast food sector: A survey on university students in Jabodetabek (Jalarta, Bogor, Depok, Tangerang, Bekasi) Indonesia International Journal of Scientific and Research Publication. 1-7.

Saleem. (2014). The Impact of Service Quality on Customer Satisfaction, Customer Loyalty and Brand Image: Evidence from Hotel 75 Industry of Pakistan. Middle East Journal of Scientific Research, 19 (5), 706-711.

Saravanakumar. (2012). Social media marketing. Life Science Journal, 9(4), 4444-4451.

Sasmita. (2015). Young consumers' insight on brand equity. Effects of brand association, brand loyalty, brand awareness and brand image. International Journal of Retail \& Distribution Management, 276-292.

Schmidt. (2015). Industry 4.0 potentials for creating smart products: empirical research results. International Conference on Business Informative Systems, 16-27. 
Segars. (n.d.). Re-examining Perceived Ease of Use and Usefulness: a confirmatory Factor Analysis. MIS 1993.

Sekaran, U. (2013). Research Methods for Business A Skill Building Approach. Journal Network and System Science.

Shahin. (2015). The key determinants of e-service quality. International Management Conference.

Shehzad. (2013). Factors Influencing the Cellphone Brand Loyalty of Swedish Generation. Pg 56

Singh. (2016). Factors Affecting Brand Loyalty in the Footwear Industry: A study of Ludhiana District. International Journal of Research.4, (139-149)

So. (2013). The influence of customer brand identification on hotel brand evaluation and loyalty development. International Journal of Hospitality Management, 3 (4), 3141.

Spang. (2017). An examination of the uses and gratification of utilitarian and experiential online shoppers. Rochester Institute of Technology.

Thomas. (2017, 8 6). Anticipate: Knowing What Customers Need Before They Do. Retrieved from http://site.ebrary.com/lib/samk/home.action

Tsai-Yuan. (2013). A Study of the Factors that Influence the Brand Loyalty of Taiwanese Adolescents with Respect to Purchasing Mobile. The Case of Taichung City. Problems and Perspectives in Management, 11(2). 